\title{
PENERAPAN MODEL PEMBELAJARAN CIRCUIT LEARNING TERHADAP KEMAMPUAN KOMUNIKASI MATEMATIS SISWA KELAS X SMA N 1 PASIR PENYU
}

\author{
Ramadhani Fitri' ${ }^{1}$, Agusfitriani ${ }^{2}$ \\ ${ }^{1}$ Program Studi Pendidikan Matematika STKIP Insan Madani Airmolek \\ ${ }^{2}$ Mahasiswa Program Studi Pendidikan Matematika STKIP Insan Madani Airmolek \\ Ramadhanifitri44@yahoo.co.id ${ }^{1}$, agusfitriani3916@gmail.com ${ }^{2}$
}

\begin{abstract}
This study aims to determine students' mathematical communication skills using the Circuit Learning learning model. This research is a Quasi Experiment study with the design of the Randomized Subjects Posstest Only Control Group Design. The study population was all students of class X SMA N 1 Pasir Penyu. The sampling technique uses random sampling. The instrument used was a mathematical communication ability test in the form of a description. Data were analyzed statistically by the Independent Samples T-Test. Based on the results of the t test, tcount in the rejection area of $\mathrm{HO}$ can be concluded that the mathematical communication skills of students taught with the circuit learning learning model are better than conventional learning.
\end{abstract}

Keywords: Mathematical Communication, Circuit Learning.

\begin{abstract}
Abstrak. Penelitian ini bertujuan untuk mengetahui kemampuan komunikasi matematis siswa dengan menggunakan model pembelajaran Circuit Learning. Penelitian ini merupakan penelitian Quasi Experiment dengan rancangan Randomized Subjects Posstest Only Control Group Design. Populasi penelitian yaitu seluruh siswa kelas X SMA N 1 Pasir Penyu. Teknik pengambilan sampel menggunakan random sampling. Instrumen yang digunakan tes kemampuan komunikasi matematis berupa uraian. Data dianalisis secara statistik dengan Uji Independent Samples T-Test. Berdasarkan hasil uji $t$ tersebut, thitung berada didaerah penolakan $\mathrm{H}_{0}$ dapat disimpulkan bahwa kemampuan komunikasi matematis siswa yang di ajar dengan model pembelajaran circuit learning lebih baik daripada pembelajaran konvensional.
\end{abstract}

Kata Kunci: Komunikasi Matematis, Circuit Learning.

\section{PENDAHULUAN}

Pendidikan merupakan salah satu aspek yang sangat penting untuk mempersiapkan individu agar dapat menghadapi pesatnya perkembangan IPTEK, dalam pendidikan formal salah satu mata pelajaran yang dapat digunakan untuk membangun cara berfikir siswa adalah matematika. Siagian (2017) matematika merupakan ilmu pengetahuan yang diperoleh dengan bernalar yang menggunakan istilah yang didefinisikan dengan cermat, jelas, dan akurat representasinya dengan lambang-lambang atau simbol dan memiliki arti serta dapat digunakan dalam pemecahan masalah yang berkaitan dengan bilangan. Disamping itu juga dapat dikatakan bahwa matematika itu terdiri atas unsurunsur yang saling berkaitan bukan saling terpisah, dalam matematika ada hierarki yaitu adanya unsur yang satu merupakan syarat dari yang lain atau suatu konsep atau entitas matematika dibangun dari konsep atau entitas lainnya.

Pembelajaran matematika mendorong kepercayaan diri siswa dalam kemampuan bernalar, berargumentasi, dan menilai dalam kemampuan berpikirnya sendiri. Oleh Karena itu, matematika sangat penting dipelajari disetiap tingkat jenjang pendidikan, mulai dari jenjang pendidikan dasar sampai jenjang perguruan tinggi. Salah satu tujuan penting dalam pembelajaran matematika adalah komunikasi matematis. Komunikasi matematis perlu menjadi fokus perhatian dalam pembelajaran matematika, sebab melalui komunikasi siswa dapat mengorganisisasi dan mengkonsolidasi berfikir matematisnya dan siswa dapat 
mengekplorasi ide-ide matematika. Dengan kata lain komunikasi matematika merupakan kemampuan yang fundamental dan esensial dalam pembelajaran matematika, dimana harus dibangun dengan kokoh dan ditumbuhkembangkan dalam diri siswa. Turmudi (2008:73) menjelaskan bahwa aspek komunikasi hendaknya menjadi aspek penting dalam pembelajaran matematika. Aspek komunikasi melatih siswa untuk dapat mengkomunikasikan gagasannya, baik komunikasi lisan maupun komunikasi tulis.

Ansari (2012:22) yang menyatakan kompetensi yang dikembangkan dalam komunikasi matematik sebagai alat bantu berpikir, alat untuk memecahkan masalah, mengambil keputusan dan sebagai aktivitas sosial yang merupakan bagian terpenting untuk mempercepat pemahaman siswa. NCTM (2000:60) menyatakan bahwa kemampuan komunikasi matematik yang perlu dibangun dalam diri siswa dengan tujuan mereka dapat: 1) memodelkan situasi dengan lisan, tulisan, gambar, dan secara aljabar; 2) merefleksikan dan mengklarifikasikan dalam berfikir mengenai gagasan matematika dalam berbagai situasi; 3) mengembangkan pemahaman terhadap gagasan-gagasan matematika ternasuk peranan defenisi-defenisi dalam matematika; 4) menggunakan ketrampilan membaca, mendengar, dan melihat untuk menginterprestasikan dan mengevaluasi gagasan matematika; 5) mengkaji gagasan matematika melalui konjektur dengan alasan meyakinkan.

Berdasarkan hasil observasi yang dilakukan di kelas X di SMA N 1 Pasir Penyu, ditemukan bahwa kemampuan siswa dalam memahami, menginterpretasi dan menilai ide matematik yang disajikan dalam tulisan, lisan atau bentuk gambar (visual) masih belum optimal. Hal ini terlihat dari persentase kemampuan komunikasi matematis siswa diantaranya 76,471\% atau 26 siswa belum mampu menyampaikan ide kedalam bahasa matematika dengan berbicara, menulis, demonstrasi, dan menggambarkannya dalam bentuk visual. Kemudian 59,38\% atau 19 siswa mampu membaca simbol, serta $40 \%$ atau 13 siswa belum mampu mengkomunikasikan dengan tulisan.

Keadaan ini mempengaruhi hasil belajar matematika siswa tersebut. Hasil belajar matematika siswa pada ulangan harian semester II kelas X Sekolah Menengah Atas Negeri 1 Pasir Penyu Tahun Pelajaran 2015/2016 dapat disimpulkan bahwa siswa yang memperoleh nilai dibawah KKM masih banyak. Untuk itu perlu pengembangan pembelajaran matematika dengan mendesain agar menarik minat siswa dan menumbuhkan dorongan untuk belajar sehingga mereka terlibat aktif dalam proses pembelajaran.

Salah satu alternatif pembelajaran yang inovatif diduga dapat menumbuh kembangkan kemampuan komunikasi matematis siswa yaitu dengan menerapkan model pembelajaran circuit learning. Huda (2014) menjelaskan bahwa Circuit learning merupakan pembelajaran pikiran dan perasaan dengan pola penambahan (adding) dan pengulangan (repetition). Pembelajaran ini diawali dengan diskusi tanya jawab tentang materi yang akan dipelajari, menyajikan peta konsep, menjelaskan peta konsep, membagi kelompok, mengisi LKS yang disertai dengan peta konsep, menjelaskan tata cara mengisi, pelaksanaan preseentasi tiap kelompok dan memberikan pujian (reward). Pembelajaran circuit learning yaitu suatu pembelajaran yang dilaksanakan secara berkelompok dan pembelajarannya sudah dipeta konsep, dan menggunakan gambar yang sesuai dengan pelajaran yang akan diajarkan serta kemampuan komunikasi siswa akan berkembang karena siswa mengisi lembar kerja siswa (LKS) dengan bahasa sendiri. Syahrial (2017) menjelaskan secara keseluruhan strategi circuit learning dapat meningkatkan keaktifan siswa dalam belajar sehingga meningkatkan hasil belajar matematika siswa.

Model circuit learning adalah model pembelajaran yang memaksimalkan dan mengupayakan pemberdayaan pikiran dan dengan pola bertambah (adding) dan mengulang (repetion). Pada dasarnya mengulang adalah untuk menghubungkan informasi baru dengan pengetahuan awal yang ada dalam struktur kognitif siswa. Model pembelajaran circuit 
learning dapat membantu siswa dalam meningkatkan kreatifitasnya serta membantu dalam meningkatkan kemampuan komunikasi matematis siswa tersebut. Hal ini ditunjukkan dalam membuat catatan, pada proses pembelajaran ini siswa dituntut kreatif dengan pola pikirnya melalui peta kosep-bahasa, khusus-catatan tulis susun.

\section{METODE}

Penelitian ini merupakan penelitian Quasi Experimental Design dengan bentuk Randomized Subjects Posstest Only Control Group Design., dapat digambarkan pada Tabel berikut.

Tabel 1. Desain Penelitian

\begin{tabular}{cc|c|c|}
\hline & Group & Variabel Terikat & Posttest \\
\cline { 2 - 4 } $\mathrm{R}$ & Eksperimen & $\mathrm{X}$ & $\mathrm{T}$ \\
\hline $\mathrm{R}$ & Kontrol & - & $\mathrm{T}$ \\
\hline
\end{tabular}

Sumber: Darmadi (2013)

Keterangan:

$\mathrm{R}$ : Randomisasi

$\mathrm{X}$ : Perlakuan

$\mathrm{T}$ : Posttes

Metode pengambilan sampel secara cluster (kelompok) random sampling. Diperoleh hasil bahwa kelas X.7, ditetapkan sebagai kelas eksperimen yang pembelajarannya menggunakan model pembelajaran circuit learning dan kelas X.6 ditetapkan sebagai kelas kontrol yang pembelajarannya menggunakan model konvensional.

Teknik pengumpulan data berupa tes. Instrument penelitian ini yaitu tes kemampuan komunikasi matematis siswa, jenisnya berupa uraian. Teknik analisa data pada penelitian ini untuk menguji hipotesis secara statistik dengan uji Independent Samples T-Test atau uji t. Sebelum dilakukan uji $t$ terlebih dahulu melakukan uji normalitas dan homogenitas dari kedua kelas sampel. Analisis ini dilakukan terhadap data hasil posttes yaitu tes kemampuan komunikasi matematis siswa.

\section{HASIL DAN PEMBAHASAN}

Data kemampuan komunikasi matematis siswa diperoleh dari hasil peritungan secara statistik dapat dilihat pada Tabel 2 berikut.

Tabel 2. Deskripsi Hasil Analisis Data Kemampuan Komunikasi

\begin{tabular}{ccccc}
\hline Kelas & $\mathbf{N}$ & $\overline{\boldsymbol{x}}$ & Varians & $\boldsymbol{s}$ \\
\hline Eksperimen & 34 & 77,1 & 60,6 & 7,8 \\
\hline Kontrol & 32 & 72,7 & 67,1 & 8,2 \\
\hline
\end{tabular}

Dari Tabel di atas terlihat bahwa terdapat perbedaan nilai rata-rata hasil tes akhir siswa dan variansi antara kelas eksperimen dan kelas kontrol. Rata-rata yang diperoleh kelas eksperimen adalah 77,088 sedangkan pada kelas kontrol adalah 72,690, dimana ratarata pada kelas eksperimen lebih tinggi daripada kelas kontrol. Variansi kelas eksperimen adalah 60,567 dan variansi kelas kontrol adalah 67,125.

Untuk menarik kesimpulan dari hasil penelitian yang dilakukan, maka data yang diperoleh dari tes kemampuan komunikasi matematis siswa dilakukan analisis data secara statistik yaitu uji hipotesis dengan uji Uji Independent Samples T-Test atau uji t. Sebelum dilakukan uji $t$ terlebih dahulu penulis melakukan uji normalitas dan homogenitas. 
Uji Normalitas

Tabel 3. Hasil Perhitungan Uji Normalitas

\begin{tabular}{|lccccc}
\hline Sam Nilai Sig & Nilai $\boldsymbol{\alpha}$ & Lmaks & Ltab & Keterangan \\
Dat & 0,84 & 0,05 & 0,102 & 0,109 & Normal
\end{tabular}

Dari Tabel 3 terlihat bahwa pada kelas sampel (data) $\mathrm{L}_{\text {maks }}=0.102<\mathrm{L}_{\text {tabel }}=0,109$ atau nilai Sig. $0,84>\alpha=0,05$ maka sebaran kelas sampel (data) diatas dapat disimpulkan berdistribusi normal.

Uji Homogenitas

Uji homogenitas pada penilitian ini menggunakan uji $F$.

Tabel 4. Hasil Perhitungan Uji Homogenitas

\begin{tabular}{|c|c|c|ccc}
\hline Kelompok & $\mathbf{N}$ & $\mathbf{S}^{\mathbf{2}}$ & ${ }^{\mathbf{F}}$ hitung & ${ }_{\text {Ftabel }}$ & Keterangan \\
\hline Eksperimen & 34 & 60,6 & \multirow{2}{*}{0,90} & 1,06 & \multirow{2}{*}{ Homogen } \\
\hline Kontrol & 32 & 67,1 & & & \\
\hline
\end{tabular}

Dari tabel di atas terlihat bahwa $F_{\text {hitung }}<F_{\text {tabel }}$, artinya kedua kelas mempunyai variansi yang homogen.

Uji Hipotesis

Uji hipotesis pada penelitian ini menggunakan (Uji $t$ ) Independent Samples T-Test dengan bantuan software SPSS. Berdasarkan hasil uji $t$ tersebut, diperoleh nilai thitung $=$ 2,238 $>\mathrm{t}_{\text {tabel }}=1,664(\mathrm{df}=6)$, sehingga $\mathrm{t}_{\text {hitung }}$ berada didaerah penolakan $\mathrm{H}_{0}$ atau berada diluar antara -1,664 dan 1,664 sehingga dapat disimpulkan bahwa hipotesis nol $\left(\mathrm{H}_{0}\right)$ ditolak dan hipotesis kerja $\left(\mathrm{H}_{\mathrm{a}}\right)$ diterima. Dengan demikian hipotesis yang diajukan dalam penelitian ini diterima yaitu "kemampuan komunikasi matematis siswa dengan penggunaan model pembelajaran circuit learning lebih baik dari pada kemampuan komunikasi matematis siswa dengan pembelajaran konvensional".

Berdasarkan hasil penelitian yang telah dilakukan ternyata kemampuan komunikasi matematis siswa yang di ajar dengan model pembelajaran circuit learning lebih baik daripada kemampuan kemampuan komunikasi matematis yang diajar dengan pembelajaran konvensional. Hal ini dikarenakan pada tahap penggunaan model pembelajaran circuit learning siswa dilatih untuk menghubungkan benda nyata gambar, dan diagram kedalam ide matematika, kemudian menjelaskan ide, situasi, dan relasi matematika siswa secara lisan atau tulisan, dengan benda nyata, gambar, grafik dan aljabar, serta menyatakan peristiwa sehari-hari dalam bahasa simbol matematika.

Berdasarkan hasil analisis jawaban tes kemampuan komunikasi matematis siswa dari deskripsi tiap-tiap indikator yang dipilih maka diperoleh hasil bahwa kemampuan komunikasi kelas eksperimen lebih tinggi daripada kemampuan komunikasi kelas kontrol. Hal ini juga sesuai dengan hipotesis pada penelitian ini, yaitu "Kemampuan komunikasi matematis siswa dengan model pembelajaran circuit learning lebih baik daripada kemampuan komunikasi matematis siswa dengan pembelajaran konvensional". Hal ini sejalan dengan hasil penelitian Dewi, dkk (2014) dan Hakim dan Mintohari (2015) menyebutkan bahwa penerapan circuit learning pada proses pembelajaran di kelas mampu memberikan perbedaan yang signifikan dalam peningkatan prestasi belajar siswa. Dengan demikin, circuit learning dapat menjadi alternatif pembelajaran dalam mengatasi kesulitan belajar siswa.

\section{KESIMPULAN}

Berdasarkan hasil analisis data diperoleh nilai $t_{\text {hitung }}=2,238>t_{\text {tabel }}=1,664$, maka dapat disimpulkan bahwa kemampuan komunikasi matematis siswa dengan penerapan model circuit learning lebih baik daripada kemampuan komunikasi matematis siswa 
dengan penerapan pembelajaran konvensional pada kelas X Sekolah Menengah Atas Negeri 1 Pasir Penyu.

DAFTAR PUSTAKA

Ansari, B. I. 2012. Komunikasi Matematik Strategi Berfikir dan Manajemen Belajar: Konsep dan Aplikasi. Banda Aceh: PeNA

Darmadi, H. 2013. Metode Penelitian dan Sosial. Bandung: Alfabeta.

Dewi, dkk. 2014. Pengaruh Model PembelajaranCircuit Learning Berbantuan Media Audiovisual terhadap Hasil Belajar Siswa SD N 1 PejejngTahun Pelajaran 2013/2014. Jurnal Mimbar PGSD Universitas Pendidikan Ganesha, 2(1)

Hakim, A. R. Dan Mintohari. 2015. Pengaruh Model Circuit Learning terhadap Hasil Belajar Siswatema Ekosistem di Sekolah Dasar. Jurnal Penelitian Pendidikan Guru Sekolah dasar Universitas Negeri Surabaya, 3(2), 239-248.

Huda, M. 2014. Model-Model Pengajaran Dan Pembelajaran. Yogyakarta: Pustaka Pelajar.

NCTM (National Council of Teachers of Mathematics). 2000 Principles and Standarts for mathematics, Reaston, VA: NCTM.

Siagian, M. D. 2017. Pembelajaran Matematika Dalam Persfektif Konstruktivisme. NIZHAMIYAH (Jurnal Pendidikan Islam dan Teknologi Pendidikan), VII(2), 61-73.

Syahrial. 2017. Penerapan Strategi Pembelajaran Circuit Learning: Suatu Upaya dalam Meningkatkan Hasil Belajar Siswa. Lemma, III(2), 40-51.

Turmudi. 2008. Landasan Filsafat dan Teori Pembelajaran Matematika (Berparadigma Eksploratif dan Investigatif). Jakarta: Leuser Cipta Pustaka. 